\title{
Heterogeneity among clam harvesters in northwest Mexico shapes individual adaptive capacity
}

\author{
$\underline{\text { Kara E. Pellowe }}^{1,2}$ and Heather M. Leslie ${ }^{1,2,3}$
}

\begin{abstract}
Temporal variability driven by environmental shifts, biological processes, and socioeconomic fluctuations is inherent in natural resource-based sectors, including fisheries. In navigating these changes as opportunities for transformation, individual decisions play a key role. Understanding individual adaptive capacity, i.e., the ability to cope under changing or novel circumstances, and considering how this capacity is affected by diverse individuals' interactions with formal fisheries policy may allow a better understanding of adaptive capacity in a rapidly changing world. In Loreto Bay National Park, Baja California Sur, Mexico, the Mexican chocolate clam is an important source of food and livelihoods and is harvested by a diverse group of fishers. Understanding the diversity of fishers, their decision-making processes, and their adaptive strategies is essential for both anticipating fishery outcomes and predicting the capacity of different types of fishers to adapt to environmental and economic change. We used semistructured interviews with clam harvesters to ask: (1) What types of fishers exist within the chocolate clam fishery? (2) How do they differ in their adaptive strategies? and (3) What are the implications of diverse fisher types on individual adaptive capacity? We find that fishers of chocolate clams in this region operate within both the formal and informal sectors, have varied fishing strategies, and can be characterized into four discrete types. We also find that heterogeneity among fishers affects their individual capacities to adapt to changing conditions and disturbances, and fisheries policy constrains fishers' access to options by limiting secure access to fishing rights. Maintaining a diverse suite of adaptive strategies is essential for individuals to cope in the face of future disturbance and change. Likewise, maintaining heterogeneity in the fishery, by ensuring that multiple fisher types are equipped to adapt to future change, will strengthen adaptive capacity within the fishery and community.
\end{abstract}

Key Words: adaptive capacity; Baja California Sur; diversification; heterogeneity; Mexico; small-scale fisheries

\section{INTRODUCTION}

Temporal variability is inherent in natural resource-based sectors, including fisheries (Stoll et al. 2017). This variability is driven by changes in environmental and biological processes, as well as socioeconomic shifts based on market dynamics and consumer demand (Adger 2000). Individuals' adaptive strategies help them navigate and respond to these changes, and individual agency can be vital in shaping the dynamics of the broader social-ecological system (SES; Biggs et al. 2010, Westley et al. 2013, Frawley et al. 2019a). Understanding how individuals make decisions and adapt is key to predicting how they will fare under changing conditions in the future (Coulthard and Britton 2015). Heterogeneity among fishers has consequences both for the sustainability of fished populations and for fishers' individual capacity to adapt to future change (Coulthard and Britton 2015, Stoll et al. 2017, Frawley et al. 2019b). Adaptive capacity is defined as the ability of systems to design or change their structure in response to environmental or socioeconomic variability such that they maintain the ability to cope under new circumstances (Adger et al. 2005, Armitage and Plummer 2010). Monitoring adaptive responses and considering how community and system-level adaptive capacity is affected by individuals' abilities to adapt may allow a deeper understanding of feedbacks, trade-offs, and potential improvements to approaches for assessing and building adaptive capacity (Cinner et al. 2015).

Adaptive strategies that fishers employ include changes in how, when, where, and what to fish (Wilson 2017). Strategies involving changes in fishing activities include changing harvest method (Cinner et al. 2015), engaging in seasonal fishing effort (Sievanen
2014), and changing the intensity of fishing activity (Cinner et al. 2011, Stoll et al. 2017). Changes to the intensity of harvest may have either dampening or amplifying feedbacks on the exploitation of target species, depending on fishers' socioeconomic characteristics and livelihood options, which influence their responses to change (Cinner et al. 2011). Fishers may also change or rotate harvest locations (Sievanen 2014, Young et al. 2019), diversify their fisheries portfolios, or shift to high-value fisheries (Perry et al. 2011, Stoll et al. 2017). Fisheries portfolio diversification reduces the risk to fishers of interannual variation in stock abundance and market value (Kasperski and Holland 2013, Finkbeiner 2015) and is a signal of fishers' adaptive capacity. Maintaining or expanding alternate sources of income via livelihood diversification (Béné 2009, Galappaththi et al. 2019), or relying on social networks to provide employment or cover basic needs, can help fishers navigate times when primary target species are scarce (Löfgren 1972, Perry et al. 2011, Boag et al. 2018). Another common adaptation strategy among fishers is mobility, or moving to follow sources of income (Pinsky and Fogarty 2012, Sievanen 2014). Additional strategies include proactive approaches such as altering habitat to accommodate desirable species (Boag et al. 2018), and wait-and-see approaches in which changes in behavior are delayed until additional information is collected (Perry et al. 2011; see Table 1 for a full description of adaptive strategies employed by fishers around the world).

The adoption of adaptive strategies often requires resources or inputs that may not be available to all fishers. For example, new information or knowledge may be needed before a fisher can change harvest times or locations (Wilson et al. 2013). To expand

${ }^{1}$ Darling Marine Center, University of Maine, ${ }^{2}$ Ecology and Environmental Sciences Graduate Program, University of Maine, ${ }^{3}$ School of Marine Sciences, University of Maine 
Table 1. Examples of adaptive strategies employed by small-scale fishers globally. Adaptive strategies often require financial and informational inputs from the fishers who employ them. Financial inputs require financial capital to purchase equipment such as boats, other motor vehicles, and fishing gear. Informational inputs include new knowledge and skills.

\begin{tabular}{|c|c|c|c|}
\hline Type of adaptive strategy & Input required & Strategy & Reference \\
\hline How to fish & Financial & Multiple harvest methods & Cinner et al. (2015) \\
\hline When to fish & Informational & Seasonal fishing effort & Sievanen (2014) \\
\hline Where to fish & Informational & Rotate harvest location & Sievanen (2014) \\
\hline What to fish & Financial & Fisheries portfolio diversity & Perry et al. (2011), Stoll et al. (2017) \\
\hline \multirow{2}{*}{ How and when to generate income } & Informational and financial & Livelihood diversity & Allison and Ellis (2001), Béné (2009) \\
\hline & & Reliance on social networks & Perry et al. (2011), Löfgren (1972) \\
\hline Where to generate income & Informational & Mobility (seasonal or long term) & Sievanen (2014) \\
\hline Proactive & Informational & Seeding, alter the environment & Boag et al. (2018) \\
\hline Wait & None & Wait and see & Perry et al. (2011) \\
\hline
\end{tabular}

or move into new fishing areas, fishers may be required to obtain additional permits and longer range fishing vessels, and there may be higher fuel requirements to power vessels beyond their current fishing range. Formal fisheries policies may limit fishers' access to licenses and secure fishing rights and may influence their ability to rely on fishing as a stable livelihood (Cinti et al. 2010). Financial capital inputs, including new fishing gear, as well as informational inputs, may be required before a fisher can adopt new harvest methods or diversify fishing portfolios (Stoll et al. 2017). The ability to diversify is also increasingly bound by regulatory enclosure (Murray et al. 2010). Variation among fishers in terms of social and economic capital, as well as factors such as culture, perception, and individual risk profiles, influence which adaptive strategies they adopt (Frawley et al. 2019b). This variation affects each fishers' individual ability to adapt to disturbance and change and may also have consequences for the broader adaptive capacity of the fishery SES (Folke et al. 2010).

Understanding of the full spectrum of fishers, their decisionmaking processes, and their adaptive strategies is essential for both anticipating fishery outcomes and predicting the capacity of different types of fishers to adapt to future change. We focus on a small-scale fishery on the Gulf of California coast of Baja California Sur, Mexico, where fishers experience temporal and spatial variability in resource abundance, environmental conditions, and market demand (Pellowe and Leslie 2017), and where formal policies restrict access to fishing rights (Sievanen 2014). Here, we ask: (1) What types of fishers exist within the chocolate clam fishery of Loreto Bay National Park? (2) How do they differ in their adaptive strategies? and (3) What are the implications of diverse fisher types on individual adaptive capacity? We focus not only on the formal fishery, but also on the less visible informal sector that is often excluded from fisheries management. The inclusion of these fishers is critical to comprehensive fisheries studies, particularly in cases where the number of informal fishers is equal to or greater than the number of formal fishers. We argue that: (1) There are multiple, discrete fisher types, characterized by harvest strategy and status of inclusion in the formal fishery; (2) Fisher types employ different suites of strategies to adapt to economic and environmental change; and (3) Adaptive strategies vary between fishers engaged in the formal and informal fishery because of formal fisheries policies that create an economic barrier to the access of secure fishing rights and markets.

\section{STUDY AREA}

In the region of Loreto Bay National Park, Baja California Sur, Mexico, fishers of the Mexican chocolate clam Megapitaria squalida vary in their demographic characteristics and harvest strategies. The Mexican chocolate clam is a culturally and economically important species in this region that provides food and income to many households. The clam can be found in shallow waters along the coast, requires little equipment to harvest, and for many households, serves as a safeguard in times of scarcity. Many locals have childhood stories of digging in the sand with their toes or learning to dive in the clear waters of the Gulf of California, searching for signs of the clams' siphons, just visible on the surface of the ocean floor. The traditional method of harvest remains free diving. This technique involves holding one's breath and diving to the ocean floor to search for clams buried in the sand. The technical inputs of free diving are low; many freediving fishers use a mask, snorkel, fins, and in some cases, a float constructed of empty milk containers to hold their catch. Many fishers still use this traditional technique, although the method formally recognized under current fisheries policy is hookah diving. Hookah diving involves a boat outfitted with a gasolinepowered air compressor that pumps air through long plastic tubing to a diver at the ocean floor. The hookah technique allows fishers to access greater depths and to remain on the ocean floor for up to $4 \mathrm{~h}$ at a time. Compared to the 60-90-s breath holds of the most experienced free divers, hookah diving's extended periods at depth allow for efficient and high-yield harvests. Under current fisheries policy, fishers of the Mexican chocolate clam must hold a species-specific permit. Obtaining this permit requires proof of ownership and the registration of a boat, typically a 6-9-m fiberglass boat known as a panga, an outboard motor, and an air compressor for hookah diving. The costs associated with these requirements are prohibitive for many fishers. For this reason, many Mexican chocolate clam fishers in this region operate outside of the formal, permitted fishery (Pellowe, personal observation). The informal sector of the fishery, which accesses clams exclusively via free diving, is a large and heterogeneous group that falls outside the purview of fisheries management and lacks secure access to fishing rights.

\section{METHODS}

From May to August 2015, we conducted in-depth, semistructured interviews (Bernard 2018) with 35 chocolate clam fishers in Loreto, Juncalito, Ligüí, and Ensenada Blanca, Baja 
Table 2. Types of fishers associated with the Mexican chocolate clam fishery in Loreto Bay National Park, Baja California Sur, Mexico. Typologies are based on permit status, primary gear type, and type of operational arrangement.

\begin{tabular}{lccll}
\hline \hline Fisher type & $N$ & Permit & Gear type & Operational arrangement \\
\hline Libres & 13 & No & Snorkel & Independent \\
Buzos de compresor & 17 & Yes & Fiberglass boat, hookah compressor & Independent or cooperative member \\
Permisionarios libres & 2 & Yes & Fiberglass boat, snorkel & Independent or cooperative member \\
Contratados & 3 & No & Hookah compressor & Contractor \\
\hline
\end{tabular}

California Sur, Mexico. To understand the full spectrum of fishers involved in the fishery, care was taken to recruit and interview both permit-holding and nonpermit-holding individuals. At the time of the interviews, there were approximately 20-25 people harvesting clams under a permit (independent permit holders or cooperative members), and an estimated 50-75 people harvesting clams without a permit in this region. Of the 35 interviews conducted, 22 were audio-recorded, 3 of which were of nonpermit-holding fishers. Most nonpermit-holding fishers declined to be recorded, many citing a fear of being connected to the data shared during the interview and then receiving sanctions related to their extralegal activities. Interview participants were recruited via snowball sampling (Morgan 2008), beginning with contacts established during previous fieldwork in this region, and a list of contact information for chocolate clam permit holders as of May 2015. We identified the remaining interviewees by asking each participant to recommend other clam fishers in the region. Many nonpermit-holding fishers were wary to participate in an interview or to recommend others. This led to a smaller number of interviews with nonpermit holders than with permit holders.

Interviews were conducted in Spanish, the first language of the participants. Interviews occurred in person, lasted between $30 \mathrm{~min}$ and $2 \mathrm{~h}$, and took place on the beach or at participant's homes. All interviews were confidential because of the sensitive legal nature of fishing without a permit. Fishermen ranged in age from 28 to 55 and had lived in the Loreto Bay region between 15 and 54 yr. Interviews were guided by a set of open-ended questions and collected data on fishers' socioeconomic characteristics, reliance on clam harvest as a source of income, other sources of income, frequency of clam harvest, and effort. We used descriptive questions (Schatzman and Strauss 1973) to ask fishers about the factors influencing their fishing decisions, including where, when, and how they harvest clams. We also collected information on other species harvested, changes fishers had observed in the clam fishery over time, and whether their harvest practices and target species had changed over time.

Written notes, including quotations of fishers' responses, were recorded by two interviewers during each interview (Schatzman and Strauss 1973). Because many participants declined to have their responses audio-recorded, and recorded interviews were heavily skewed toward permit-holding fishers, we relied on the written responses captured by interviewers for qualitative data analysis. We employed an inductive approach (Strauss 1987) to define fisher types and to code fisher characteristics and adaptive strategies, with themes and categories emerging from analysis of interview notes by the primary researcher who conducted the interviews (KP). Typologies were constructed based on emergent themes from interview data and included primary harvest method, type of operation, and permit status.

\section{RESULTS}

Our observations and interviews with clam fishers indicate that there are two major and two minor fisher types: (1) libres, nonpermit-holding, free-diving fishers; (2) buzos de compresor, permit-holding, hookah-diving fishers; (3) permisionarios libres, permit-holding, free-diving fishers; and (4) contratados, nonpermit-holding, hookah-diving fishers who contract their skills to permit holders (Table 2). The first type of fishers, libres $(N=13)$, harvest chocolate clams primarily via free-diving with a mask, snorkel, and fins. They operate independently and do not harvest chocolate clams under a permit. The second type of fishers, buzos de compresor $(N=17)$, harvest chocolate clams using a 7-9-m fiberglass boat with outboard motor called a panga, outfitted with a gasoline-powered compressor for hookah diving. This type of fisher holds a permit for harvesting chocolate clams and operates either independently under his own permit or as a member of a permit-holding fishing cooperative. Permisionarios libres $(N=2)$ and contratados $(N=3)$ are rare and differ from the first two groups in important ways. Like buzos de compresor, permisionarios libres hold permits for chocolate clams, operate either independently or as cooperative members, and harvest clams from a boat, but they do so via free-diving with mask, snorkel, and fins. Contratados do not hold their own permits and are not members of cooperatives, but they harvest clams as independent contractors for permit holders or formal cooperatives for a daily rate. They harvest clams from a boat using hookah equipment that is owned by the permit holder or cooperative to whom they contract their skills. Fishers using the free-diving method reported collecting, on average, 422 clams/ harvest-day, whereas compressor divers reported collecting 2740 clams/harvest-day.

Fishers reported that one of the primary benefits of having a permit is being able to harvest and sell higher volumes of catch for better prices (Table 3). Three buzos de compresor participants stated that their primary reasons for fishing under a permit are the ability to sell more clams and the ability to obtain better prices for their catch than would be possible without a permit. This difference in catch and price was described qualitatively by participants. The benefits of holding a permit were echoed by libres, two of whom said they would prefer to obtain a permit because it would increase the value of their product, and four of whom said that having a permit would reduce the risk of problems with authorities. However, 9 of the 35 participants, including two buzos de compresor, stated that the expense and difficulty of obtaining a permit limits some fishers from harvesting clams as part of the formal sector. One participant, a libre, stated that he 
Table 3. Primary reasons affecting fishers' decisions to obtain or not to obtain a species-specific fishing permit for the Mexican chocolate clam. Reason categories emerged from participants' responses to an interview question about what factors affect their decision to obtain or not to obtain a fishing permit for this species.

\begin{tabular}{|c|c|c|}
\hline Decision & Reason & Illustrative quote \\
\hline \multirow[t]{5}{*}{ Obtain a permit } & $\begin{array}{l}\text { Avoid problems with fishery authorities or avoid } \\
\text { sanctions }\end{array}$ & $\begin{array}{l}\text { "With a permit... you can harvest the clams you want without } \\
\text { consequence." (Participant 24); "I want to avoid problems with } \\
\text { authorities and be in accordance with the law." (Participant 19) }\end{array}$ \\
\hline & Easier to sell product & $\begin{array}{l}\text { "The price is higher if you have a permit, and it's easier to sell [clams]. } \\
\text { You can sell them wherever you want." (Participant 14) }\end{array}$ \\
\hline & Higher price paid for clams harvested under a permit & $\begin{array}{l}\text { "The price is higher if you have a permit, and it's easier to sell [clams]. } \\
\text { You can sell them wherever you want." (Participant 14) }\end{array}$ \\
\hline & Ability to use hookah equipment & "With a permit, you can use equipment." (Participant 1) \\
\hline & Ability to contribute to clam management & $\begin{array}{l}\text { "If I had a permit, I could help regulate the clams by giving a truthful } \\
\text { record of catch. I want to contribute to better management." } \\
\text { (Participant } 30 \text { ) }\end{array}$ \\
\hline \multirow[t]{2}{*}{$\begin{array}{l}\text { Do not obtain a } \\
\text { permit }\end{array}$} & Expensive equipment required & $\begin{array}{l}\text { "I don't have the money. The equipment is very expensive." (Participant } \\
\text { 9) }\end{array}$ \\
\hline & $\begin{array}{l}\text { Extensive documentation needed for permit application; } \\
\text { bureaucracy }\end{array}$ & $\begin{array}{l}\text { "The problem is the bureaucracy. There are many roadblocks to getting } \\
\text { a permit." (Participant } 32 \text { ); "It is not easy to get a permit." (Participant } \\
23 \text { ) }\end{array}$ \\
\hline
\end{tabular}

remains unpermitted because of the "many roadblocks": "We are illegal [fishers] because we do not have an option," he said. Another participant, a buzo de compresor, stated, "Everyone wants to get a permit. Many don't have the equipment required, but they still [harvest clams]." The expense of obtaining the equipment necessary to apply for a chocolate clam permit was a primary reason given by participants for remaining in the informal sector.

Interview participants varied in their reliance on chocolate clam fishing as a source of income. Twenty-one participants $(60 \%)$ reported that $100 \%$ of their income comes from fishing, and of these, five participants reported that their sole source of income is chocolate clam fishing. On average, $82 \%$ of participants' income comes from some type of fishing activity, and of this, $41 \%$ of fishing income comes from chocolate clam fishing. These proportions did not vary considerably among fisher types (Table 4). Sixteen participants $(46 \%)$ reported having additional, nonfishing sources of income throughout the year. Two participants reported that $100 \%$ of their income comes from fishing but that they take additional jobs when needed. Additional sources of income reported included park monitoring, education construction and masonry, transport and sale of potable water, glass manufacturing, tourism, bus or truck driving, agriculture, landscaping, and restaurant work.

Eighty percent of participants indicated that they had observed changes in the ocean over the past 10-20 yr. Sixty percent said that they had observed changes in chocolate clam populations, including declines in the abundance and size of clams. Two participants said that they believed the changes in clams were cyclical, rather than directional (i.e., they expected to see increases as well as decreases over the long term). Participants reported seasonal variability in market demand for chocolate clams, as well as seasonal shifts in environmental conditions in Loreto Bay National Park, including changes in water temperature and wind strength and direction throughout the year. Eight fishers expressed the belief that free diving has a lower impact on clam populations than does hookah diving, and that the expansion of hookah diving is a primary reason for the declines in clam populations they have observed. One participant stated, "If there weren't compressors in Loreto Bay, the clams would never disappear." He believes that compressors and the hookah divers who use them are responsible for the declines in clam populations that he has observed. Another participant echoed this sentiment, "If everyone dove with a compressor like that, the clams would be gone." This individual does not want to use equipment to fish but is trying to obtain a permit to avoid problems with fishery authorities.

All participants reported engaging in at least one adaptation strategy, and the most adaptive strategies reported by an individual fisher, a buzo de compresor, was five. The most common strategy reported was rotating harvest sites (Table 5). Ninetyseven percent of participants (34 of 35) reported rotating harvest locations on a daily to monthly basis. Fishers switched among harvest locations when clams became scarce, appeared too small, or when environmental factors, including wind and waves, limited their access to certain sites. Individual fishers reported harvesting from two to nine different clam banks over the course of a typical year, indicating high spatial variability in fishers' harvest activities. Other adaptation strategies commonly reported included maintaining diverse fishing portfolios $(63 \%)$ and engaging in seasonal fishing effort of chocolate clams (63\%). Seasonal fishing effort, i.e., temporal variability in chocolate clam effort throughout a typical year, was reported by all types of fishers except permisionarios libres. Recall, however, the small number of permisionarios libres in our sample $(N=2)$. Sixty-two percent of libres, $77 \%$ of buzos de compresor, and $33 \%$ of contratados reported varying their fishing effort seasonally throughout a typical year. Rotating harvest location and engaging in seasonally variable fishing effort are strategies that require informational, but not necessarily financial, inputs.

Participants' adaptation strategies were related to fisher type. Higher percentages of buzos de compresor reported using multiple harvest methods ( $41 \%$ ) and maintaining diverse fishing portfolios $(82 \%)$ compared to libres ( $0 \%$ and $39 \%$, respectively). Conversely, 
Table 4. Measures related to fishers' proportional economic dependence on chocolate clam fishing and on all fishing, proportion of fishers who have noticed changes in the ocean and in clam populations, and average number of strategies employed by fishers. Each measure is presented for the entire participant pool and for each fisher type. These measures were calculated from the responses of 35 fishers to questions presented during semi-structured interviews.

\begin{tabular}{|c|c|c|c|c|c|}
\hline \multirow[b]{2}{*}{ Measure } & \multicolumn{5}{|c|}{ Fisher type } \\
\hline & All & Libres & $\begin{array}{l}\text { Buzos de } \\
\text { compresor }\end{array}$ & $\begin{array}{l}\text { Permisionarios } \\
\text { libres }\end{array}$ & Contratados \\
\hline Proportion of income from chocolate clams $(\%)$ & 41 & 45 & 36 & 40 & 50 \\
\hline Proportion of income from all fishing (\%) & 82 & 77 & 85 & 65 & 100 \\
\hline $\begin{array}{l}\text { Proportion of participants who noticed changes in the } \\
\text { ocean in the past } 20 \text { years }(\%)\end{array}$ & 80 & 77 & 82 & 50 & 100 \\
\hline $\begin{array}{l}\text { Proportion of participants who noticed changes in clam } \\
\text { populations }(\%)\end{array}$ & 60 & 77 & 41 & 50 & 100 \\
\hline Average number of adaptive strategies & 3.0 & 2.6 & 3.5 & 2.5 & 2.7 \\
\hline
\end{tabular}

$62 \%$ of libres, almost double that of buzos de compresor $(35 \%)$, report maintaining diverse livelihoods. Although interview questions were not designed specifically to capture data on mobility, reliance on social networks, proactive approaches, or wait-and-see strategies, it is likely that many participants engage in these approaches in addition to the strategies explicitly reported. In addition, despite interviews not being designed to capture proactive approaches, seeding of small clams was a strategy reported by three participants $(9 \%)$. No participants explicitly reported wait-and-see approaches; however, one participant, a buzo de compresor, reported relying on social networks to cover his basic needs during times of financial hardship.

\section{DISCUSSION}

We found that heterogeneity among fishers affects their individual capacities to adapt to changing conditions and disturbances and may affect both economic and ecosystem-related fishery outcomes. Fishers of chocolate clams in Loreto Bay National Park operate within both the formal and informal sectors, have various combinations of methodologies and operations, and fall into four discrete groups. We found differences in the adaptive strategies used by fishers of these different types. Adaptive strategies employed by fishers worldwide include using multiple harvest methods, changing spatial distribution of effort via rotation of harvest sites, maintaining alternate sources of income (both fisheries and livelihood portfolio diversity), and redistributing effort among the fisheries in which they participate (Fuller et al. 2017). Fishers also rely on social networks during times of scarcity (Löfgren 1972), move to other locations to follow sources of income (Sievanen 2014), and engage in proactive approaches to seed or encourage the growth and survival of desirable species (Boag et al. 2018). Understanding how individuals make decisions, and what options they have for responding to changing conditions, is critical for understanding individual resilience (Coulthard and Britton 2015). Limits to individual agency affect not only how fishers interact with their resources and the adaptation strategies they adopt, but also the success of local resource management (Bennett et al. 2018).

All fishers in our study reported at least one adaptive strategy. On average, they maintain three adaptive strategies, suggesting that chocolate clam fishers engage in a suite of behaviors that buffer them against environmental change and dynamic markets. Spatial variability in fishing effort, a strategy requiring informational inputs, was reported by nearly all fishers interviewed. This spatial variability, which took the form of rotating harvest locations, occurred on a daily to monthly basis. Seasonal variation in fishing effort was another common strategy, reported most often by fishers with fishing portfolios composed of multiple, seasonal target species. Fishers in Baja California Sur experience highly seasonal catches, partly due to environmental variability (Pellowe and Leslie 2017). Many of the clam fishers in our study harvest chocolate clams seasonally as a complement to the other fisheries in which they participate.

We found that in some cases, the rate at which participants reported adaptive strategies was related to fisher type. Higher percentages of buzos de compresor, permit-holding, hookahdiving fishers, reported using multiple harvest methods and maintaining diverse fishing portfolios compared to libres, the nonpermit-holding, free-diving fishers. This finding makes sense, given the financial investments that buzos de compresor have made in the fishing sector to obtain the equipment and permits required to harvest Mexican chocolate clams legally. Access to financial capital can enhance fishers' abilities to diversify their livelihoods and adapt to change without putting additional strain on fished resources (Haque et al. 2015). However, almost twice as many libres maintain nonfishing sources of income as do buzos de compresor. Their diverse livelihoods buffer them against their lack of secure access to fishing rights and their unstable income from Mexican chocolate clam harvests. Libres have lower investment in the fishing sector and receive lower daily clam harvests and fishing income compared to fishers who harvest clams via hookah diving. Formal policies prevent fishers without permits from selling their catch to the formal market, including to restaurants, and they thus receive orders for Mexican chocolate clams less reliably. Small-scale fishers worldwide experience poor or variable market access (Haque et al. 2015), and informal fishers may be the most vulnerable to market dynamics. One of the primary benefits of having a permit, according to fishers in our study, is the ability to sell to the formal market, where they can sell high volumes of catch for better prices. By supplementing clam income from other sources, libres adapt to the lower harvest rates, less reliable demand, and lower prices they receive as informal fishers. Maintaining options and flexibility is at the core of adaptive 
Table 5. Proportions of chocolate clam fishers (\%) reporting specific adaptive strategies. These measures were calculated from the responses of 35 fishers to questions presented during semistructured interviews.

\begin{tabular}{|c|c|c|c|c|c|c|}
\hline \multicolumn{2}{|c|}{ Adaptive strategy reported } & \multicolumn{5}{|c|}{ Fisher type } \\
\hline Type & Strategy & All & Libres & $\begin{array}{l}\text { Buzos de } \\
\text { compresor }\end{array}$ & $\begin{array}{l}\text { Permisionarios } \\
\text { libres }\end{array}$ & Contratados \\
\hline \multirow[t]{4}{*}{ Change fishing } & Multiple harvest methods & 31 & 0 & 41 & 50 & 67 \\
\hline & Seasonal fishing effort & 63 & 62 & 76 & 0 & 33 \\
\hline & Rotate harvest location & 97 & 92 & 100 & 100 & 100 \\
\hline & Fisheries portfolio diversity & 63 & 38 & 82 & 50 & 67 \\
\hline Change income & Livelihood diversity & 49 & 62 & 35 & 50 & 0 \\
\hline
\end{tabular}

capacity (Folke et al. 2010). However, fisheries policy constrains fishers' access to options by limiting secure access to fishing rights to those fishers with high financial capital.

Despite informal fishers' desire to access formal markets and avoid sanctions, they are constrained by fisheries policy and their lack of financial capital, which prevents them from meeting the requirements for a fishing permit. Although many informal fishers would prefer to harvest under a permit, many also stated that they prefer the traditional free-diving method over hookah diving. Fishers whose primary method of harvest is hookah diving collect 6.5 times more clams per harvest-day than do fishers who free dive. This difference in harvest efficiency and effort may have significant ecological consequences for the fishery. Current fisheries policies for the Mexican chocolate clam and other species in the Gulf of California region provide the wrong incentives for sustainable use of marine resources (Cinti et al. 2010). In Loreto, current management of the Mexican chocolate clam encourages the adoption of high-impact fishing methods. Further, the exclusion from the formal fishery of fishers who employ the traditional method of free diving leads to underreporting of catch, which in turn affects the creation of future fisheries management for the species. Fishers we interviewed attribute observed declines in the abundance and size of clam populations to the expansion of hookah diving. This observation is coupled with a common belief among fishers of all types that free diving has a lower impact on clam populations.

Current fisheries policy results in de facto encouragement to adopt higher impact harvest methods, high rates of unreported catch, and thus, inaccurate estimates of total harvest in Loreto Bay's Mexican chocolate clam fishery. Inaccuracies in the data informing management may lead to inappropriate quota limits and declines in clam populations. Many fishers believe that the shift toward hookah diving has resulted in higher overall fishing pressure and reductions in clam populations. This finding is consistent with recent emphasis on the need for conservation policy that is aligned with local ethics, values, and motivations (Lubchenco et al. 2016, Nyborg et al. 2016). Alienation of the informal sector (libres and permisionarios libres) via a lack of access to secure fishing rights, formal sanctions, and exclusion from decision-making processes has also led to tension between formal and informal groups. Previous work in Baja California Sur has found that the permitting structure limits fishers' ability to migrate seasonally in response to seasonal shifts in target species (Sievanen 2014), and that market accessibility privileges wealthy actors (Frawley et al. 2019b). In Loreto, participatory processes meant to encourage the inclusion of diverse actors in marine resource management have resulted in internal exclusion, whereby the participation of certain actors and groups is limited (Peterson 2011). Appropriate marine management requires deepened participation of diverse actors, including marginalized groups, and shifts in the power balance among actors (Gomes de Araujo et al. 2017), particularly in the Gulf of California region (Cinti et al. 2010). Increased participation of marginalized groups such as informal fishers requires redefining how institutions operationalize participation. Formal mechanisms to increase the participation of marginalized groups are often obstructed by powerful groups that define the meaning of participation (Gomes de Araujo et al. 2017). Effective marine management requires knowledge of the local context, including the decision-making processes of diverse actors and their individual abilities to adapt to change, as well as policies that take into account local ethics, values, and motivations (Bennett et al. 2018).

Observed differences among fishers in individual adaptive capacity can lead to various levels of individual vulnerability to future environmental or socioeconomic change. A comprehensive understanding of this heterogeneity in fishers' adaptive capacity is necessary for management strategies that address the needs of diverse fishers. Heterogeneity among fishers' adaptive capacity has also been found in other systems that are economically dependent on the fisheries sector (Steneck et al. 2011, Stoll et al. 2017). In many of these cases, fisheries portfolio diversification represents a primary adaptive strategy that varies widely among individual fishers (Stoll et al. 2017). Barriers to fisheries portfolio diversification, including the difficulty of obtaining permits, influence fishers' individual adaptive capacities and have consequences at the fishery scale. Reductions in economic diversity limit adaptive capacity and leave both fishers and fisheries vulnerable to future economic and environmental change (Steneck et al. 2011). Mediating such vulnerability requires policies that support social, biological, and economic diversity.

\section{CONCLUSION}

Fishers are adept at solving problems and adapting to the inherent variability of the marine environment in which they work (Acheson 1981). The variability that fishers commonly experience is due to changes in environmental and biological processes as well as market dynamics and demand (Adger 2000). The chocolate clam fishers we interviewed actively employ adaptive strategies and make fishing and livelihood decisions in response to changing conditions. Fisher type is, in many cases, related to fishers' access to financial resources coupled with formal fisheries policies, which 
limit the access of secure fishing rights and markets in which to sell catch to those fishers with the highest financial capital. These policies, together with socioeconomic variability among individual fishers, influence and limit the adaptive strategies fishers use. Informal fishers engage in almost as many adaptive strategies as formal fishers, and the strategies they employ generally require less input of financial capital. Informal fishers obtain higher proportions of their total income from chocolate clam fishing than do formal fishers, yet they are subject to highly variable demand and lower prices. They are thus particularly vulnerable to the environmental and economic variability inherent in the fishery. Informal fishers often lack the resources to obtain permits, are excluded from fishery decision-making processes, and are subject to costly sanctions for fishing without a permit. Such fishers are keenly aware of changes in chocolate clam populations and worry about how increasing use of hookah diving will affect clams and their own livelihoods. As one libre fisher stated, "As the sea is used up, so I will be too." These fishers buffer themselves against vulnerabilities by maintaining diverse livelihood portfolios and engaging in various strategies to adapt to change. Maintaining a diverse suite of adaptive strategies is essential for individuals to cope in the face of future disturbance and change. Likewise, maintaining heterogeneity in the fishery via fisheries policies that ensure multiple fisher types are equipped to adapt to future change will strengthen adaptive capacity at the fishery and community levels.

Responses to this article can be read online at: http://www.ecologyandsociety.org/issues/responses. php/11297

\begin{abstract}
Acknowledgments:
We thank Hector Trinidad, the team of Eco-Alianza Loreto, and Juan Ulibarria for field assistance and identification of potential interview participants. We also thank Sofia Castelló, Kai Kopecky, Santiago Domínguez Sánchez, and Beni Martinez for assistance in the field, and Alfredo Baeza for logistical assistance. We extend our heartfelt thanks to the communities onshore Loreto Bay National Park: Ensenada Blanca, Juncalito, Liguï, Loreto, and Nopoló, and to the fishers who participated in this study. This paper was improved by comments from Joshua Stoll and Timothy Frawley, as well as from two anonymous reviewers. Funding for this study was provided by the U.S. NSF through DEB 1632648 (HL, PI).
\end{abstract}

\section{LITERATURE CITED}

Acheson, J. M. 1981. Anthropology of fishing. Annual Review of Anthropology 10:275-316. https://doi.org/10.1146/annurev. an.10.100181.001423

Adger, W. N. 2000. Social and ecological resilience: Are they related? Progress in Human Geography 24(3):347-364. https://doi. org/10.1191/030913200701540465

Adger, W. N., T. P. Hughes, C. Folke, S. R. Carpenter, and J. Rockström. 2005. Social-ecological resilience to coastal disasters. Science 309(5737):1036-1039. https://doi.org/10.1126/science.1112122
Allison, E. H., and F. Ellis. 2001. The livelihoods approach and management of small-scale fisheries. Marine Policy 25 (5):377-388. https://doi.org/10.1016/S0308-597X(01)00023-9

Armitage, D., and R. Plummer, editors. 2010. Adaptive capacity and environmental governance. Springer, Berlin, Germany. https:// doi.org/10.1007/978-3-642-12194-4

Béné, C. 2009. Are fishers poor or vulnerable? Assessing economic vulnerability in small-scale fishing communities. Journal of Development Studies 45(6):911-933. https://doi.org/10.1080/00220380902807395

Bennett, N. J., T. S. Whitty, E. Finkbeiner, J. Pittman, H. Bassett, S. Gelcich, and E. H. Allison. 2018. Environmental stewardship: a conceptual review and analytical framework. Environmental Management 61(4):597-614. https://doi.org/10.1007/s00267-017-0993-2

Bernard, H. R. 2018. Research methods in anthropology: qualitative and quantitative approaches. Sixth edition. Rowman and Littlefield, Lanham, Maryland, USA.

Biggs, R., F. R. Westley, and S. R. Carpenter. 2010. Navigating the back loop: fostering social innovation and transformation in ecosystem management. Ecology and Society 15(2):9. https://doi. org/10.5751/ES-03411-150209

Boag, A. E., J. Hartter, L. C. Hamilton, N. D. Christoffersen, F. R. Stevens, M. W. Palace, and M. J. Ducey. 2018. Climate change beliefs and forest management in eastern Oregon: implications for individual adaptive capacity. Ecology and Society 23(4):1. https://doi.org/10.5751/ES-10355-230401

Cinner, J. E., C. Folke, T. Daw, and C. C. Hicks. 2011. Responding to change: using scenarios to understand how socioeconomic factors may influence amplifying or dampening exploitation feedbacks among Tanzanian fishers. Global Environmental Change 21(1):7-12. https://doi.org/10.1016/j.gloenvcha.2010.09.001

Cinner, J. E., C. Huchery, C. C. Hicks, T. M. Daw, N. Marshall, A. Wamukota, and E. H. Allison. 2015. Changes in adaptive capacity of Kenyan fishing communities. Nature Climate Change 5(9):872-876. https://doi.org/10.1038/nclimate2690

Cinti, A., W. Shaw, R. Cudney-Bueno, and M. Rojo. 2010. The unintended consequences of formal fisheries policies: Social disparities and resource overuse in a major fishing community in the Gulf of California, Mexico. Marine Policy 34(2):328-339. https://doi.org/10.1016/j.marpol.2009.08.002

Coulthard, S., and E. Britton. 2015. Waving or drowning: an exploration of adaptive strategies amongst fishing households and implications for wellbeing outcomes. Sociologia Ruralis 55 (3):275-290. https://doi.org/10.1111/soru.12093

Finkbeiner, E. M. 2015. The role of diversification in dynamic small-scale fisheries: lessons from Baja California Sur, Mexico. Global Environmental Change 32:139-152. https://doi.org/10.1016/ j.gloenvcha.2015.03.009

Folke, C., S. R. Carpenter, B. Walker, M. Scheffer, T. Chapin, and J. Rockström. 2010. Resilience thinking: integrating resilience, adaptability and transformability. Ecology and Society 15(4):20. https://doi.org/10.5751/ES-03610-150420 
Frawley, T. H., L. B. Crowder, and K. Broad. $2019 a$. Heterogeneous perceptions of social-ecological change among small-scale fishermen in the central Gulf of California: implications for adaptive response. Frontiers in Marine Science 6:78. https://doi.org/10.3389/fmars.2019.00078

Frawley, T. H., E. M. Finkbeiner, and L. B. Crowder. $2019 b$. Environmental and institutional degradation in the globalized economy: lessons from small-scale fisheries in the Gulf of California. Ecology and Society 24(1):7. https://doi.org/10.5751/ ES-10693-240107

Fuller, E. C., J. F. Samhouri, J. S. Stoll, S. A. Levin, and J. R. Watson. 2017. Characterizing fisheries connectivity in marine social-ecological systems. ICES Journal of Marine Science 74 (8):2087-2096. https://doi.org/10.1093/icesjms/fsx128

Galappaththi, E. K., J. D. Ford, and E. M. Bennett. 2019. A framework for assessing community adaptation to climate change in a fisheries context. Environmental Science and Policy 92:17-26. https://doi.org/10.1016/j.envsci.2018.11.005

Gomes de Araujo, L., F. de Castro, R. Rodrigues de Freitas, M. A. Regina de Mattos Vieira, and C. S. Seixas. 2017. Struggles for inclusive development in small-scale fisheries in Paraty, southeastern coast of Brazil. Ocean and Coastal Management 150:24-34. https://doi.org/10.1016/j.ocecoaman.2017.02.014

Haque, C. E., C. J. Idrobo, F. Berkes, and D. Giesbrecht. 2015. Small-scale fishers' adaptations to change: the role of formal and informal credit in Paraty, Brazil. Marine Policy 51:401-407. https://doi.org/10.1016/j.marpol.2014.10.002

Kasperski, S., and D. S. Holland. 2013. Income diversification and risk for fishermen. Proceedings of the National Academy of Sciences 110(6):2076-2081. https://doi.org/10.1073/pnas. 1212278110

Löfgren, O. 1972. Resource management and family firms: Swedish west coast fishermen. Pages 82-103 in R. Andersen and C. Wadel, editors. North Atlantic fishermen: anthropological essays of modern fishing. Memorial University Press, St. John's, Canada.

Lubchenco, J., E. B. Cerny-Chipman, J. N. Reimer, and S. A. Levin. 2016. The right incentives enable ocean sustainability successes and provide hope for the future. Proceedings of the National Academy of Sciences 113(51):14507-14514. https://doi. org/10.1073/pnas.1604982113

Morgan, D. L. 2008. Snowball sampling. Page 81 in L. M. Given, editor. The Sage encyclopedia of qualitative research methods. Volumes 1 and 2. Sage, Los Angeles, California, USA.

Murray, G., T. Johnson, B. J. McCay, M. Danko, K. St. Martin, and S. Takahashi. 2010. Cumulative effects, creeping enclosure, and the marine commons of New Jersey. International Journal of the Commons 4(1):367-389. https://doi.org/10.18352/ijc.148

Nyborg, K., J. M. Anderies, A. Dannenberg, T. Lindahl, C. Schill, M. Schlüter, W. N. Adger, K. J. Arrow, S. Barrett, S. Carpenter, F. S. Chapin III, A.-S. Crépin, G. Daily, P. Ehrlich, C. Folke, W. Jager, N. Kautsky, S. A. Levin, O. J. Madsen, S. Polasky, M. Scheffer, B. Walker, E. U. Weber, J. Wilen, A. Xepapadeas, and A. de Zeeuw. 2016. Social norms as solutions. Science 354 (6308):42-43. https://doi.org/10.1126/science.aaf8317
Pellowe, K. E., and H. M. Leslie. 2017. Seasonal variability shapes resilience of small-scale fisheries in Baja California Sur, Mexico. Plos One 12(8):e0182200. https://doi.org/10.1371/journal. pone. 0182200

Perry, R. I., R. E. Ommer, M. Barange, S. Jentoft, B. Neis, and U. R. Sumaila. 2011. Marine social-ecological responses to environmental change and the impacts of globalization. Fish and Fisheries 12(4):427-450. https://doi.org/10.1111/j.1467-2979.2010.00402. $\underline{\mathrm{x}}$

Peterson, N. D. 2011. Excluding to include: (non)participation in Mexican natural resource management. Agriculture and Human Values 28(1):99-107. https://doi.org/10.1007/s10460-010-9258-X

Pinsky, M. L., and M. Fogarty. 2012. Lagged social-ecological responses to climate and range shifts in fisheries. Climatic Change 115(3-4):883-891. https://doi.org/10.1007/s10584-012-0599-x

Schatzman, L., and A. Strauss. 1973. Field research: strategies for a natural sociology. Prentice Hall, Englewood Cliffs, New Jersey, USA.

Sievanen, L. 2014. How do small-scale fishers adapt to environmental variability? Lessons from Baja California, Sur, Mexico. Maritime Studies 13:9. https://doi.org/10.1186/ $\underline{\mathrm{s} 40152-014-0009-2}$

Steneck, R. S., T. P. Hughes, J. E. Cinner, W. N. Adger, S. N. Arnold, F. Berkes, S. A. Boudreau, K. Brown, C. Folke, L. Gunderson, P. Olsson, M. Scheffer, E. Stephenson, B. Walker, J. Wilson, and B. Worm. 2011. Creation of a gilded trap by the high economic value of the Maine lobster fishery. Conservation Biology 25(5):904-912. https://doi.org/10.1111/j.1523-1739.2011.01717.x

Stoll, J. S., E. Fuller, and B. I. Crona. 2017. Uneven adaptive capacity among fishers in a sea of change. Plos One 12(6): e0178266. https://doi.org/10.1371/journal.pone.0178266

Strauss, A. L. 1987. Qualitative analysis for social scientists. Cambridge University Press, Cambridge, UK. https://doi. org/10.1017/CBO9780511557842

Westley, F. R., O. Tjornbo, L. Schultz, P. Olsson, C. Folke, B. Crona, and Ö. Bodin. 2013. A theory of transformative agency in linked social-ecological systems. Ecology and Society 18(3):27. https://doi.org/10.5751/ES-05072-180327

Wilson, J. 2017. Learning, adaptation, and the complexity of human and natural interactions in the ocean. Ecology and Society 22(2):43. https://doi.org/10.5751/ES-09356-220243

Wilson, J. A., J. M. Acheson, and T. R. Johnson. 2013. The cost of useful knowledge and collective action in three fisheries. Ecological Economics 96:165-172. https://doi.org/10.1016/j. ecolecon.2013.09.012

Young, T., E. C. Fuller, M. M. Provost, K. E. Coleman, K. St. Martin, B. J. McCay, and M. L. Pinsky. 2019. Adaptation strategies of coastal fishing communities as species shift poleward. ICES Journal of Marine Science 76(1):93-103. https:// doi.org/10.1093/icesjms/fsy140 